\title{
CELLULASE ENZYME PRODUCTION BY VARIOUS FUNGAL STRAINS ON DIFFERENT CARBON SOURCES
}

\author{
M. BOLLÓK and K. RÉCZEY \\ Department of Agricultural Chemical Technology, Technical University of Budapest, \\ H-1521 Budapest, Szt. Gellért tér 4. Hungary
}

(Received: 15 September 1999; accepted: 24 November 1999)

In the process of making ethanol from lignocellulosics, enzyme production is still the most crucial and costly step. Trichoderma reesei Rut C-30 is the best known cellulase producer. This fungus is very good in endo- and exoglucanase production, however, the amount of $\beta$-glucosidase excreted is not sufficient for hydrolysis. In addition, T. reesei Rut C-30 is sensitive to inhibitors generated during steam-pretreatment of wood. In the present study, two good cellulase producers were selected from 16 fungal strains and investigated regarding filter paper activity (FPU) and $\beta$-glucosidase activity using inexpensive lignocellulosic carbon sources for cultivation. T. reesei Rut C-30 proved to be a good cellulase producer, resulting in a maximum FPU of $1.39 \mathrm{FPU} \mathrm{m}^{-1}$ on washed, steam-pretreated willow, but the $\beta$-glucosidase activity was insufficient. High $\beta$-glucosidase activities were reached with $T$. viride $\mathrm{OKI}$ B1 on all substrates, with a maximum activity of $1.62 \mathrm{IU} \mathrm{ml}^{-1}$ on steam-pretreated spruce.

Keywords: cellulase production, steam pretreated wood, paper sludge, Trichoderma

As a consequence of the decrease in crude oil reserves, much research is focused on using renewable and alternative energy sources such as ethanol as a liquid fuel for transportation.

Lignocellulosics are renewable energy and carbon sources that are produced in large amounts in higher plants. The composition of woody lignocellulosics is typically: 45-56\% cellulose, 10-20\% hemicellulose, and 18-30\% lignin (CHAHAL, 1991). Sources of lignocellulosic materials include agricultural residues, wood and forestry as well as municipal solid wastes.

Cellulose can be hydrolysed to glucose, and this can be used as a carbon source by different micro-organisms for the production of single cell protein (SCP) and other chemicals (e.g.: antibiotics, enzymes, ethanol). The production of ethanol by yeast is an example of this process.

Ethanol produced from lignocellulosic biomass is an excellent fuel for internal combustion engines, and its replacement of fossil fuels could diminish air pollution and global warming (PHILIPPIDIS \& SMITH, 1995). 
Different processes have been developed for the production of ethanol from lignocellulosic materials. The most widely investigated enzymatic processes include the following steps: pretreatment of lignocellulosic substrate, enzyme production, enzymatic hydrolysis, fermentation and distillation of ethanol (BULL, 1990; CHRISTAKOPOULOS et al., 1990).

Although acidic cellulose hydrolysis is well known, the enzymatic one has a major advantage: it produces less inhibitors during both the process (BULL, 1990; GALBE et al., 1997) and the necessary pretreatment.

In the enzymatic process, the majority of the substrate undergoes hydrolysis, while about $5 \%$ is used as a carbon source for cellulase production (GALBE et al., 1997).

The cellulase enzyme system consists of three types of enzymes - endoglucanases (EG), cellobiohydrolases ( $\mathrm{CBH})$, and $\beta$-glucosidase - which act synergistically in the saccharification of cellulose. EG cleaves the internal glycosidic bonds, while CBH hydrolyses cellobiose units from the chain ends. The $\beta$-glucosidase enzyme component is very important for efficient cellulose hydrolysis because it cleaves the cellobiose units to glucose and removes them from the reaction mixture. This prevents the inhibition of cellobiohydrolases.

Many micro-organisms are able to use cellulose as their sole carbon and energy source, and produce the cellulase enzyme at the same time. Among micro-organisms, fungi are of great interest for enzyme production because they excrete enzymes extracellularly. The most investigated fungal family is the Trichoderma, and in this family Trichoderma reese $i$ is the micro-organism used most often as a cellulase enzyme producer. However, this fungus does not excrete a sufficient amount of $\beta$-glucosidase for efficient enzymatic hydrolysis.

The $\beta$-glucosidase requirement and the ratios of enzyme activities were investigated in many studies of ethanol production from lignocelluloses (GHOSH et al., 1982; SPINDLER et al., 1992; GROHMANN, 1993).

Intensive research is in progress in order to increase the amount of $\beta$-glucosidase in the enzymatic hydrolysis step such as supplementation of Trichoderma cellulase with $\beta$-glucosidase produced by good $\beta$-glucosidase producers such as Aspergillus strains (ALLEN \& STERNBERG, 1980; RÉCZEY et al., 1998); increase of $\beta$-glucosidase excretion of Trichoderma by changing the conditions of fermentation (COCHET, 1991); improvement of the pretreatment method to decrease the amount of lignin and other inhibitors released and thereby reduce the inactivation of the enzyme (EKLUND, 1994); strain improvement by mutation (AWAFO et al., 1996).

The pretreatment of lignocellulosic substrates used in ethanol production is necessary for enzymatic accessibility. The steam-pretreatment method was found to be the most suitable for this purpose (EKLUND, 1994). 
On the other hand, the pretreatment step increases the cost of inexpensive substrates compared to expensive substrates such as Solka Floc, cotton, carboxi-methylcellulose (CMC) and commercial cellulose pulp; in addition, degradation products are formed to some extent under the conditions $\left(20-30\right.$ bar, $\left.210-230^{\circ} \mathrm{C}\right)$ of steampretreatment (HATZIS et al., 1996). Trichoderma reesei shows a high sensitivity towards inhibitors generated during steam-pretreatment of wood (CHERNOGLAZOV et al., 1988). The action of enzymes is reduced and partly inhibited by adsorption on the surface of lignin as well.

Since the cost of cellulase production in the enzymatic process (including enzyme production, pretreatment, steam production, and hydrolysis) contributes a considerable amount to the total processing cost, research on this subject is essential for the reduction of the total cost (GALBE et al., 1997).

In the present study, attempts were made at finding cellulase producer strains with better $\beta$-glucosidase production and better potential in utilizing pentose fraction containing inhibitors than Trichoderma reesei Rut C-30, which was used as a reference. Seventeen fungal strains were screened for enzyme fermentation and inhibitory tolerance.

The selected fungi - Trichoderma reesei Rut C-30 and Trichoderma viride OKI B1 - were compared on different inexpensive carbon sources in shake flask fermentations with regard to filter paper degrading activity (FPU) corresponding to cellulase activity and $\beta$-glucosidase activity.

\section{Materials and methods}

\subsection{Substrates}

Solka Floc (SF), a delignified spruce pulp, was used as a reference substrate. The enzyme fermentations were carried out on washed, steam-pretreated willow (SPW), non-washed, steam-pretreated spruce (SPS), washed, steam-pretreated willow supplemented with pentose containing washing water (SPW+P) and paper sludge (PS). The substrates used, except PS, were kindly supplied by the Department of Chemical Engineering I, Lund University, Sweden. PS was obtained from Dunapack, Paper and Packaging Ltd, Hungary. The pretreatment methods for wood were described previously (RÉCZEY et al., 1998; STENBERG et al., 1999). The cellulose and lignin contents were determined according to the Hägglund methods (HÄGGLUND, 1951). The filtrate and the washing water were analyzed for sugar content by the phenol sulfuric acid method (DuBoIS et al., 1956). The results of the substrate analysis are represented in Table 1. 
Table 1

Properties of carbon sources

\begin{tabular}{lcccc}
\hline Substrate & $\begin{array}{c}\text { ODM }^{\mathrm{a}} \\
(\%)\end{array}$ & $\begin{array}{c}\text { Total sugar content } \\
\left(\mathrm{mg} \mathrm{m}^{-1}\right)\end{array}$ & $\begin{array}{c}\text { Cellulose } \\
(\%)\end{array}$ & $\begin{array}{c}\text { Lignin } \\
(\%)\end{array}$ \\
\hline Washed SPW & 40 & - & 43.5 & 49 \\
SPS & 28 & - & 43.7 & 28.15 \\
Washing water of SPW & & 9.55 & & \\
$\begin{array}{l}\text { Pentose fraction of SPS } \\
\text { Paper sludge }\end{array}$ & 30 & 96.7 & & 11 \\
\hline
\end{tabular}

${ }^{a}$ Oven dry matter

\subsection{Micro-organisms}

A total of 16 fungal strains belonging to the groups Trichoderma (9), Penicillium (2), Chaetomium (4) and Paecilomyces (1) were screened. The strains were obtained from the strain collection of the Department of Agricultural Chemical Technology, Technical University of Budapest, Hungary.

\subsection{Inoculum preparation}

All strains were maintained on agar slant containing $\left(\mathrm{g}^{-1}\right)$ : malt extract 20 , proteose peptone 1 , glucose 5 and bacto agar 20 . The fungi had been grown at $30^{\circ} \mathrm{C}$ for 2-3 weeks, and afterwards the shake flasks were inoculated by two loops of conidia. $750 \mathrm{ml}$ shake flasks were used with $10 \mathrm{~g} \mathrm{l}^{-1}$ Solka Floc in $150 \mathrm{ml}$ of Mandels medium consisting of $\left(\mathrm{g} \mathrm{l}^{-1}\right)$ : urea $0.3,\left(\mathrm{NH}_{4}\right)_{2} \mathrm{SO}_{4} 1.4, \mathrm{KH}_{2} \mathrm{PO}_{4} 2, \mathrm{CaCl}_{2} 0.3, \mathrm{MgSO}_{4} \cdot 7 \mathrm{H}_{2} \mathrm{O}$ 0.3 , bacto peptone 0.75 and yeast extract 0.25 . Trace elements were also added, using a $1 \%(\mathrm{v} / \mathrm{v})$ solution of each salt $\left(\mathrm{ml} \mathrm{l}^{-1}\right): \mathrm{FeSO}_{4} \cdot 7 \mathrm{H}_{2} \mathrm{O} 0.5, \mathrm{MnSO}_{4} 0.16, \mathrm{ZnSO}_{4} 0.14$, $\mathrm{CoCl}_{2}$ 2. The $\mathrm{pH}$ was adjusted to $5.5-6.0$ before sterilization. The inoculum was ready after 4 days of shaking at $30^{\circ} \mathrm{C}, 350 \mathrm{rpm}$.

\subsection{Shake flask fermentation}

Shake flasks of $750 \mathrm{ml}$, containing $150 \mathrm{ml}$ of medium were used for enzyme fermentation with Trichoderma reesei Rut C-30 and Trichoderma viride OKI B1. Modified Mandels medium was used, which contained the nutrients and trace elements described previously in the inoculum preparation, except the bacto peptone and the yeast extract, which were replaced by $0.375 \mathrm{~g} \mathrm{l}^{-1}$ of fodder yeast extract. Various carbon sources were added to the medium, i.e.: SPW, SPS, SPW+P, PS and SF for each strain. The amount of substrate used corresponded to the total available carbon source 
of $10 \mathrm{~g} \mathrm{l}^{-1}$. In the case of SPW+P, half of the carbon source originated from pentose fraction. Inoculum constituted $10 \%$ of the medium. Fermentations were performed in a rotary shaker at $30{ }^{\circ} \mathrm{C}, 350$ r.p.m., and the $\mathrm{pH}$ was adjusted to 5.8-6.0 once a day with $10 \% \mathrm{NaOH}$ or $\mathrm{H}_{2} \mathrm{SO}_{4}$. The samples were centrifuged and the supernatants were analyzed for filter paper activity (FPU), $\beta$-glucosidase activity, and reducing sugars content.

\subsection{Analysis}

The reducing sugar content was measured using dinitrosalicylic acid (DNS) reagent (MILLER, 1959). The enzyme activity of the samples was determined by Berghem's method (BERGHEM \& PETTERSON, 1974) for $\beta$-glucosidase activity. The cellulase activity was measured as a filter paper unit (FPU) by Mandels' procedure (MANDELS et al., 1976). A $1 \times 6 \mathrm{~cm}$ strip of a Whatman No.1 filter paper was added to a total volume of $1.5 \mathrm{ml}$ of culture filtrate and $0.05 \mathrm{M}$ citric buffer $(\mathrm{pH} 4.8)$. The samples were incubated for $1 \mathrm{~h}$ at $50{ }^{\circ} \mathrm{C}$. The hydrolysis was terminated by the addition of $3 \mathrm{ml}$ of DNS solution, followed by boiling for $5 \mathrm{~min}$. After cooling, $16.0 \mathrm{ml}$ of distilled water were added and the absorbance was read at $550 \mathrm{~nm}$. Reducing sugars in the samples were accounted for in the activity measurements.

\section{Results}

\subsection{Selection of fungal strains for enzyme production}

To select the best strains for enzyme production, their sensitivity to inhibitors was tested by growing them on agar slant containing Czapek-Dox medium prepared with $20 \mathrm{~g} \mathrm{l}^{-1}$ Solka Floc and $5 \mathrm{~g} \mathrm{l}^{-1}$ pentose sugars containing inhibitors. The enzyme production were compared by measuring FPU in shake flask experiments using SPW as a substrate. The results are shown in Table 2.

On the basis of the results, 7 strains were selected for futher examination.

The selected strains were screened for FPU and $\beta$-glucosidase production in shake flask experiments using Solka Floc as a substrate. The activities obtained are presented in Table 3.

Results showed that almost all tested strains had higher $\beta$-glucosidase activities than Trichoderma reesei Rut C-30, but most of them were growing too slowly and were producing very low levels of FPU, except for Trichoderma viride OKI B1. Regarding these results, Trichoderma viride $\mathrm{OKI}$ B1 and Trichoderma reesei Rut C-30 were chosen for the following experiments. 
Table 2

Selection of best fungal strains for enzyme production. The selected strains are written in bold

\begin{tabular}{|c|c|c|c|}
\hline \multirow[b]{2}{*}{ Tested strains } & \multicolumn{2}{|c|}{ Medium of agar slant for maintenance } & \multirow[b]{2}{*}{$\begin{array}{c}\text { FPU }\left(\mathrm{IU} \mathrm{m} \mathrm{m}^{-1}\right) \\
7 \text { th day's } \\
\text { data on SPW }\end{array}$} \\
\hline & $5 \%$ malt & $\begin{array}{l}\text { Czapek-Dox medium } \\
\text { prepared with } 20 \mathrm{~g}^{-1} \\
\text { Solka Floc }+5 \mathrm{~g} \mathrm{l}^{-1} \\
\text { pentose sugar }\end{array}$ & \\
\hline Trichoderma viride OKI B1 & ++ & ++++++ & 0.284 \\
\hline Trichoderma viride G 605 & +++ & ++++ & 0.141 \\
\hline Trichoderma konongii & ++ & +++++ & 0.236 \\
\hline Trichoderma species & +++ & +++ & 0.021 \\
\hline Trichoderma longibacillus & ++++ & ++++++ & 0.465 \\
\hline Trichoderma lignorum & ++ & ++++ & 0.03 \\
\hline Trichoderma sp. 84 & ++++ & +++ & 0.019 \\
\hline Trichoderma sp. 162 & +++++ & +++ & 0.018 \\
\hline Penicillium funiculosum BKM F-285 & +++++ & ++++ & 0.032 \\
\hline Penicillium verruculosum WA 30 & ++++ & ++++ & 0.067 \\
\hline Chaetomium elatum UAMH 2672 & ++++++ & +++++ & 0.141 \\
\hline Chaetomium funiculosum UAMA 3034 & ++++ & ++++++ & 0.147 \\
\hline Chaetomium globosum NF 00677 & +++++ & ++++ & 0.023 \\
\hline Chaetomium globosum OKI 270 & ++++ & +++++ & 0.026 \\
\hline Paecilomyces terricola QM 7721 & +++ & ++++++ & 0.21 \\
\hline Trichoderma reesei $\mathrm{Rut}$ C-30 & ++++ & ++++++ & 0.325 \\
\hline
\end{tabular}

Table 3

FPU and $\beta-$-glucosidase activity of the selected strains. Activities were obtained on $S F$ in 7 days of cultivation

\begin{tabular}{lcc}
\hline \multicolumn{1}{c}{ Examined strains } & $\begin{array}{c}\text { FPU activity } \\
\left(\mathrm{IU} \mathrm{m} \mathrm{m}^{-1}\right)\end{array}$ & $\begin{array}{c}\beta-\text { Glucosidase activity } \\
\left(\mathrm{IU} \mathrm{m}^{-1}\right)\end{array}$ \\
\hline Trichoderma reesei Rut C-30 & 0.506 & 0.256 \\
Trichoderma viride OKI B1 & 0.558 & 0.795 \\
Trichoderma longibacillus & 0.572 & 1.002 \\
Trichoderma konongii & 0.155 & 0.516 \\
Paecilomyces terricola QM 7721 & 0.235 & 0.702 \\
Chaetomium elatum UAMH 2672 & 0.117 & 0.602 \\
Chaetomium funiculosum UAMA 3034 & 0.087 & 0.038 \\
\hline
\end{tabular}




\subsection{Comparison of enzyme production on Solka Floc}

Enzyme activities were compared by cultivation of $T$. reesei Rut C-30 and T. viride OKI B1 on Solka Floc. Three parallel experiments were run for each strain with a standard deviation of $0.07 \mathrm{FPU} \mathrm{ml}^{-1}$ for filter paper activity and $0.04 \mathrm{IU} \mathrm{ml}^{-1}$ for $\beta$-glucosidase, and the mean values were calculated. The attained enzyme activities are presented in Fig. 1.
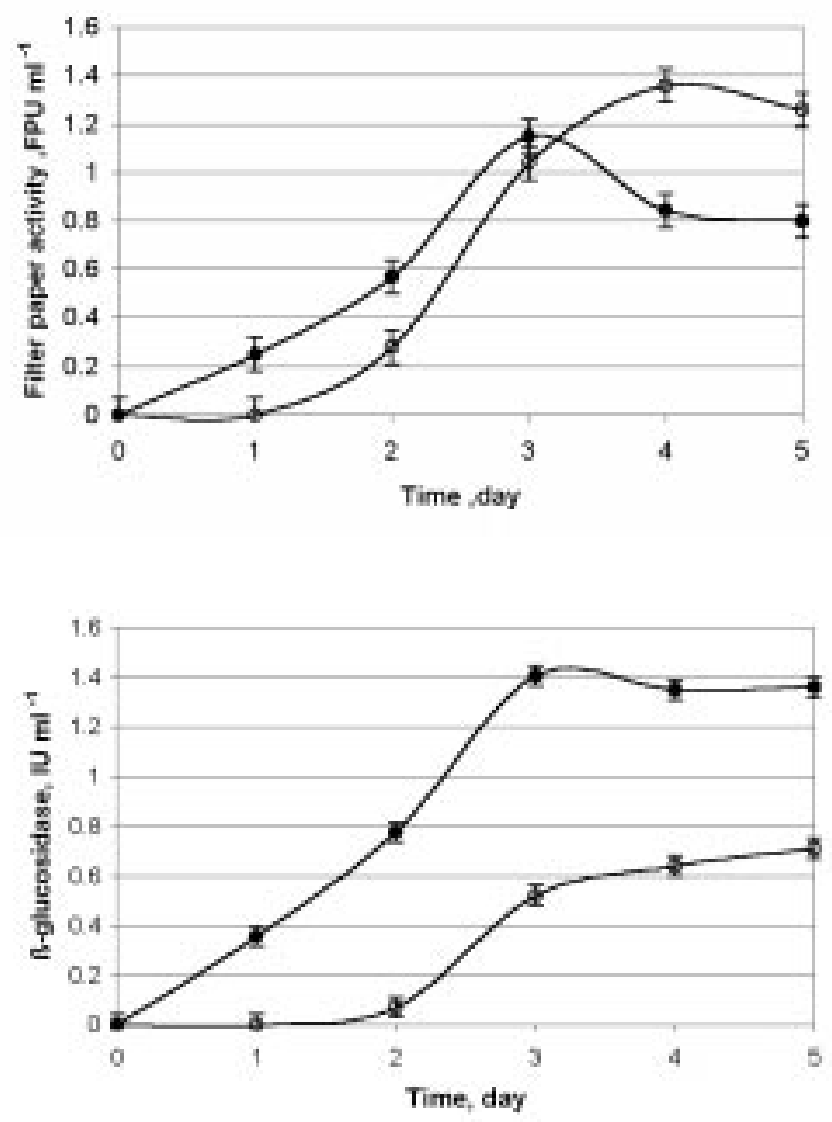

Fig. 1. Filter paper activity and $\beta$-glucosidase activity vs time for cultivation of $(\mathrm{O})$ Trichoderma reesei Rut C-30, and of (•) Trichoderma viride OKI B1 on Solka Floc carbon source 
A longer lag phase was observed in the case of T. reesei Rut C-30 in the enzyme production. The highest FPU activity of $1.36 \mathrm{FPU} \mathrm{ml}^{-1}$ was reached by $T$. reesei $\mathrm{Rut} \mathrm{C}$ 30 after 4 days of cultivation. T. viride OKI B1 was quicker, as it obtained its maximum 1.15 FPU ml ${ }^{-1}$ after 3 days of cultivation which was $15 \%$ lower compared to that reached with $T$. reesei Rut C-30. Consequently, the FPU yield of T. reesei Rut C-30 was higher, but with a productivity that is only $45 \%$ of the one reached with $T$. viride OKI B1.

$\beta$-Glucosidase activity attained with $T$. viride OKI B1 was higher throughout the fermentation resulting in a maximum activity of $1.41 \mathrm{IU} \mathrm{ml}^{-1}$, and the productivity was 1.3 times higher than that obtained with $T$. reesei Rut $\mathrm{C}-30$. The $\beta$-glucosidase activity of $T$. reesei Rut C-30 was only $0.71 \mathrm{IU} \mathrm{ml}^{-1}$ after 5 days, which is half of that obtained with $T$. viride $\mathrm{OKI} \mathrm{B} 1$.

The yields and productivities obtained are shown in Table 4.

\subsection{Cellulase enzyme production on lignocellulosic substrates}

Enzyme productions were compared using different lignocellulosic carbon sources in shake flask experiments. T. reesei Rut C-30 and T. viride OKI B1 were cultivated on SPW, SPS, SPW + P and PS, and the enzyme activities were determined. Three parallel experiments were run on each substrate for both fungal strains. The mean values of activities were calculated. The standard deviation (SD) was $0.08 \mathrm{FPU} \mathrm{m}^{-1}$ and $0.05 \mathrm{IU} \mathrm{ml}^{-1}$ for $\beta$-glucosidase. In all cases, the glucose was consumed in 2 days, and after that the enzymes were excreted into the medium.

2.3.1. Comparison of filter paper activities (FPU). Figure 2 shows the FPU activities attained on lignocellulosic carbon sources.

Table 4

The enzyme yield and productivity obtained on Solka Floc with different fungal strains

\begin{tabular}{lccccc}
\hline \multirow{2}{*}{ Fungal strains } & \multicolumn{2}{c}{ Yield (IU g ${ }^{-1}$ cellulose) } & & \multicolumn{2}{c}{ Productivity (IU $\left.~^{-1} \mathrm{~h}^{-1}\right)$} \\
\cline { 2 - 3 } \cline { 5 - 6 } & FPU & $\beta$-glucosidase & & FPU & $\beta$-glucosidase \\
\hline T. viride OKI B1 & 115 & 140.7 & & 16 & 19.5 \\
T. reesei Rut C-30 & 136 & 71 & & 7.2 & 14.4 \\
\hline
\end{tabular}



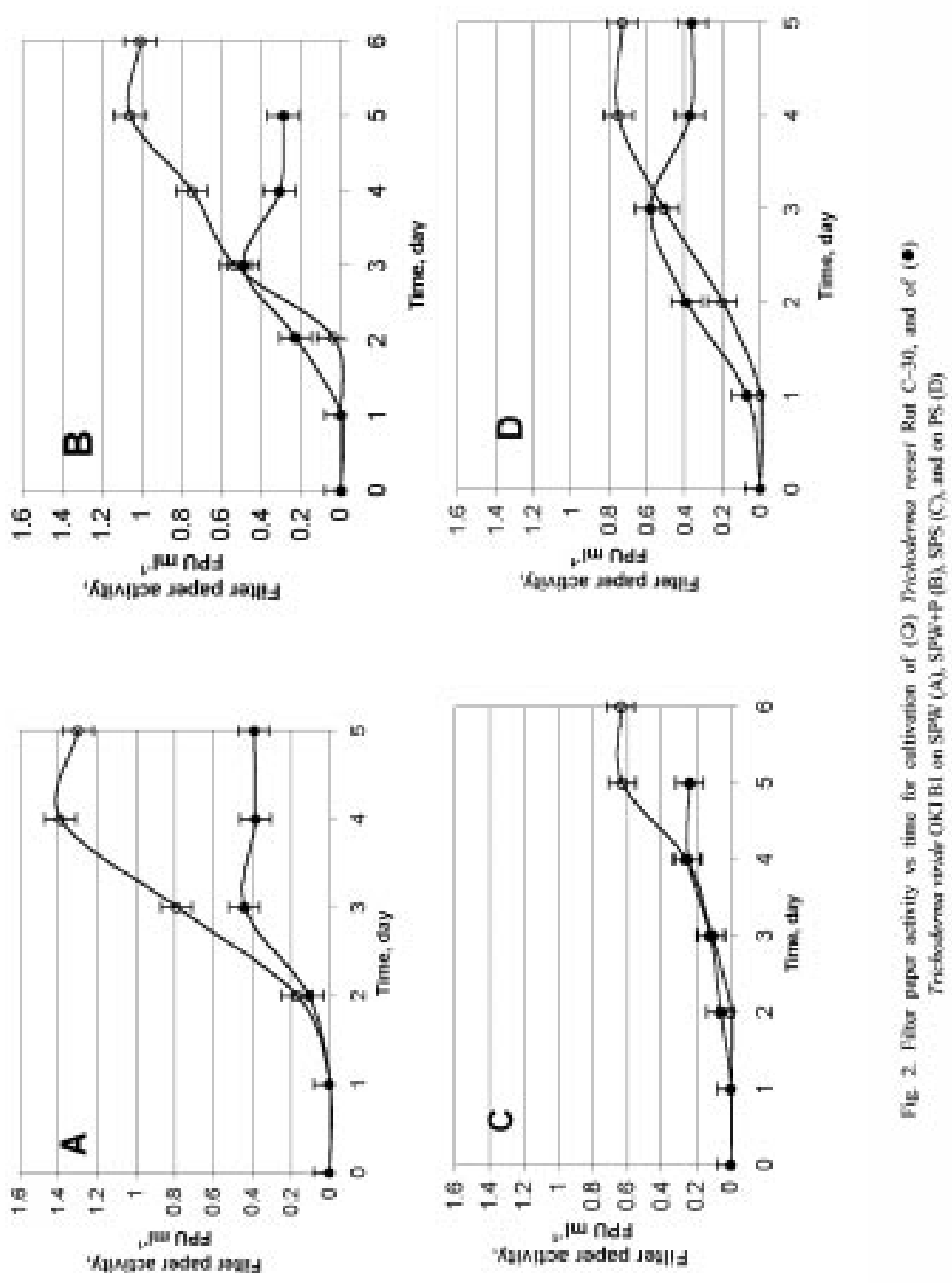
The FPU activities obtained were higher in all substrates with T. reesei Rut C-30. The best activity was reached on SPW after 4 days, which was the same, 1.39 FPU ml ${ }^{-1}$, as that obtained on Solka Floc at the same time. The enzyme production was observed after a 1 day lag phase. The FPU activity reached with $T$. reesei Rut C-30 was 3 fold higher than that attained with $T$. viride. For the SPW supplemented with washing water containing pentose, the measured activity was the same as in the case of $T$. viride OKI B1, but the obtained activity of $T$. reese $i$ was $1.06 \mathrm{FPU} \mathrm{ml}^{-1}$, which is $68 \%$ of that reached on SPW. T. viride showed a long, 2 day lag phase.

The longer lag phase and the lower attained activity show that the fungal strain has a sensitivity to the inhibitors present in the pentose fraction.

SPS proved to be a worse substrate for enzyme production than SPW. A 1 and 2 day lag phase was observed with $T$. reesei and $T$. viride, respectively. The FPU activity obtained was $54 \%$ lower than when $T$. reesei was cultivated on SPW as well as Solka Floc. The FPU activity of $T$. viride was $39 \%$ of that reached with $T$. reesei. The low enzyme activity on SPS can be explained with the more compact structure and higher lignin content of spruce (softwood) in comparison to willow (hardwood), and the difference in compositions. In addition, the SPS was unwashed which means that soluble inhibitors were present in the medium.

Using PS as a substrate, T. viride started to produce enzymes quicker, but after 4 days of cultivation $T$. reese $i$ showed the FPU activity of $0.75 \mathrm{FPU} \mathrm{ml}^{-1}$, which was 1.3 times higher than that obtained with $T$. viride.

2.3.2. Comparison of $\beta$-glucosidase activities. The $\beta$-glucosidase activities obtained are shown in Fig. 3.

The $\beta$-glucosidase activity of $T$. viride was higher on each used lignocellulosic carbon source than those attained with $T$. reesei Rut C-30. Cultivation of $T$. viride on SPW resulted in an activity of $1.46 \mathrm{IU} \mathrm{ml}^{-1}$, while $T$. reesei showed no more than $0.51 \mathrm{IU} \mathrm{ml}^{-1}$ after 5 days.

The $\beta$-glucosidase activity can be measured in the medium later than the FPU. When a part of the washed fibrous SPW was supplemented with pentose rich washing water, the obtained activity was much lower, $0.6 \mathrm{IU} \mathrm{ml}^{-1}$ and $0.14 \mathrm{IU} \mathrm{ml}^{-1}$ with $T$. viride and $T$. reesei, respectively. The reduction in $\beta$-glucosidase activity to a large extent can be explained by the sensitivity of $\beta$-glucosidase to the inhibitors present in the pentose fraction. CHERNOGLAZOV and co-workers (1988) reported that the ligninderived phenolics, which are among the degradation products formed during steampretreatment, inhibit the $\beta$-glucosidase enzyme component above all. 


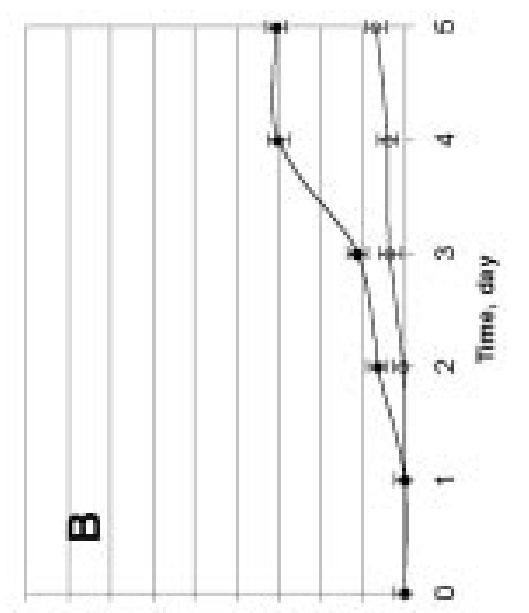

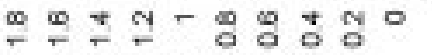

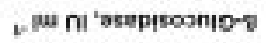

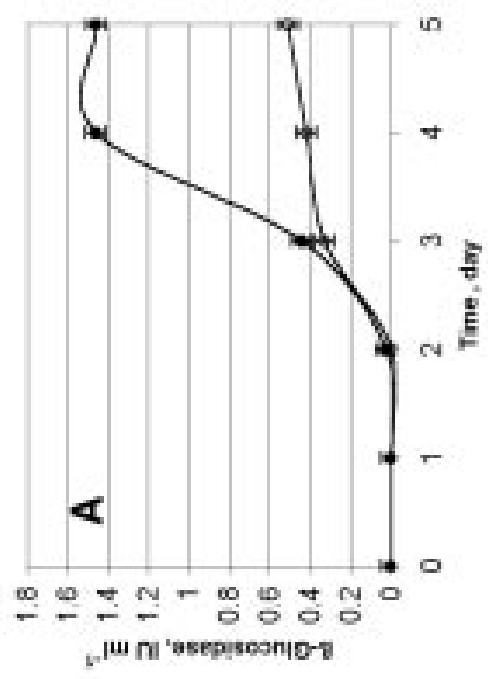

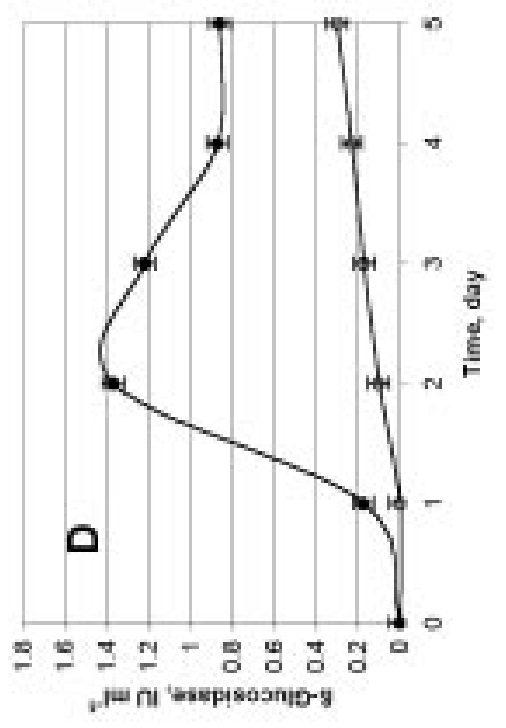

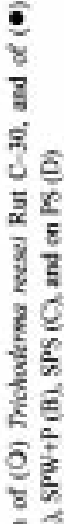

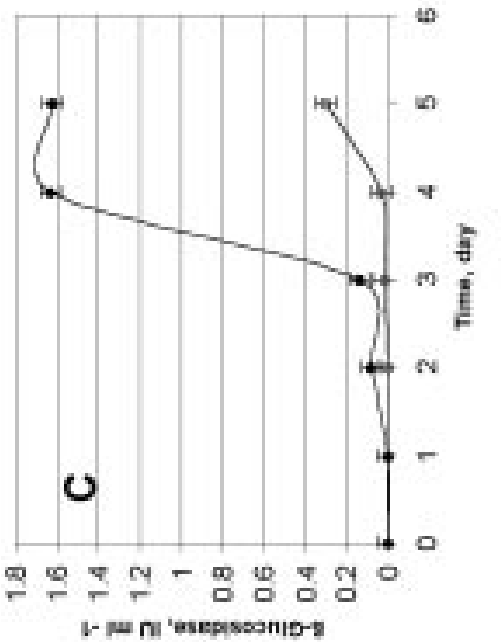

물 
Using SPS resulted in a high $\beta$-glucosidase activity of T.viride, which was $1.62 \mathrm{IU} \mathrm{ml}^{-1}$ after a long lag phase. The $\beta$-glucosidase activity reached with $T$. reesei was very low, $0.3 \mathrm{IU} \mathrm{ml}^{-1}$ after 5 days. PS proved to be a good carbon source for $T$. viride with a $\beta$-glucosidase activity of $1.37 \mathrm{IU} \mathrm{ml}^{-1}$ after 2 days. The obtained activity with $T$. reesei was only $0.3 \mathrm{IU} \mathrm{ml}^{-1}$ after 5 days.

\section{Conclusions}

Two cellulase producers were selected from 16 fungal strains based on the examination of their growth on agar medium containing pentose and their enzyme activity on Solka Floc in shake flask experiments.

Enzyme fermentation was performed with selected fungal strains on lignocellulosic carbon sources in shake flasks. The activities reached on different carbon sources compared with those obtained on SF as a control are presented in Table 5.

Table 5

Comparison of FPU and $\beta$-glucosidase activity reached on lignocellulosic carbon sources

\begin{tabular}{lccccc}
\hline \multirow{2}{*}{ Carbon sources } & \multicolumn{2}{c}{$T$. viride OKI B1 } & & \multicolumn{2}{c}{ T. reesei Rut C-30 } \\
\cline { 2 - 3 } \cline { 5 - 6 } & FPU & $\begin{array}{c}\text { B-Glucosidase } \\
(\%)\end{array}$ & & $\begin{array}{r}\text { FPU } \\
(\%)\end{array}$ & $\begin{array}{c}\beta-\text { Glucosidase } \\
(\%)\end{array}$ \\
\hline SF as a control & 100 & 100 & 100 & 100 \\
wSPW & 38 & 103.9 & & 102.2 & 91.5 \\
wSPW+P & 42.6 & 43 & 77.9 & 19.7 \\
nwSPS & 21.6 & 116 & & 46.3 & 42 \\
PS & 50.4 & 97.4 & & 55.1 & 42 \\
\hline
\end{tabular}

T. viride OKI B1 was a much quicker enzyme producer on Solka Floc than T. reesei $\mathrm{Rut} \mathrm{C}-30$. In the case of $T$. reesei $\mathrm{Rut} \mathrm{C}-30$ a lag phase was observed whereas with $T$. viride OKI B1 the enzyme activities could be detected right from the beginning. The FPU activity reached with $T$. viride OKI B1 was $84 \%$ of $T$. reesei Rut C-30's maximum activity, which was $1.36 \mathrm{FPU} \mathrm{ml}^{-1}$, resulting in an enzyme activity ratio of $0.52 \beta$-glucosidase activity to FPU activity. This is lower than the optimal ratio of $\beta$ glucosidase activity to cellulase activity required for sufficient hydrolysis, which on the basis of literature data is in the range of $0.8-1.5 \mathrm{IU}$.

The maximum value of $\beta$-glucosidase activity of $T$. viride OKI B1 was twice as high as that of the other fungus. Optimal ratio of $\beta$-glucosidase activity to FPU was obtained with T. viride OKI B1 - which was $1.2 \mathrm{IU}$ - due to the high $\beta$-glucosidase activity reached, but the FPU was lower by $15 \%$ than that obtained with $T$. reesei Rut C-30. 
A comparison of the obtained enzyme activities to those reached on the reference substrate shows that the expensive Solka Floc carbon source can be replaced with the cheap lignocellulosic substrates in enzyme fermentation. The most promising lignocellulosic substrate among the investigated ones, is the washed, steam-pretreated willow, which when used as a substrate gave higher FPU activity with $T$. reesei Rut C30 and higher $\beta$-glucosidase activity with $T$. viride OKI B1 than those reached on the reference carbon source.

In the presence of soluble inhibitors (pentose containing washing water) of SPW, the enzyme production with $T$. viride OKI B1 was inhibited significantly, and this negative effect was observed in the $\beta$-glucosidase production with $T$. reese $i$ Rut C-30 as well, but its cellulase production was only slightly reduced. Non-washed SPS proved to be an insufficient carbon source except for $\beta$-glucosidase production with $T$. viride OKI B1.

Paper sludge has to be emphasized as a carbon source despite the lower enzyme activity obtained, which was about $50 \%$ of that obtained on the reference, because it is a continuously produced waste everywhere in the world. T. viride OKI B1 was suitable for producing $\beta$-glucosidase in a high amount ( $97 \%$ of reference) even on paper sludge. Further investigation of paper sludge as a carbon source for enzyme fermentation is important because of its economical significance.

The $\beta$-glucosidase activities of $T$. viride OKI B1 were high on all lignocellulosic carbon sources except for steam-pretreated willow supplemented with pentose rich washing water. However, in every case they were higher than those of $T$. reesei Rut C30. The attained FPU activities of $T$. viride OKI B1 remained low in comparison to those obtained on Solka Floc and reached with T. reesei Rut C-30. T. reesei Rut C-30 is good in FPU production especially on steam-pretreated willow, but its $\beta$-glucosidase activity is not sufficient. T. viride OKI B1 is a promising cellulase producer, because of its high $\beta$-glucosidase activity obtained in a short time, but the FPU activity should be improved on lignocellulosic substrates. On paper sludge there was only a slight difference between the FPU activities of the two fungi, but after 2 days the $\beta$ glucosidase activity of $T$. viride OKI B1 was 4.6 times higher than that of $T$. reesei Rut $\mathrm{C}-30$. On the basis of these results, the mixed cultivation of the two investigated fungi should be promising on lignocellulosic carbon sources, above all on washed, steampretreated willow, in order to reach a convenient ratio of $\beta$-glucosidase activity to FPU in further experiments.

This research was supported by the National Research Fund of Hungary (OTKA-026047) and the National Committee for Technology Development (EU-98-D8-135, EU-98-D10-112). 


\section{References}

ALLEN, A. \& STERNBERG, D. (1980): B-Glucosidase production by A. phoenicis in stirred-tank fermentors. Biotechnol. Bioengng. Symp., 10, 189-197.

AWAFO, U. A., ChaHAL, D. S., SimPSON, B. K. \& LE, G. B. B. (1996): Production of cellulase system by selected mutants of Trichoderma reesei in solid-state fermentation and their hydrolytic potential. Appl. Biochem. Biotechnol., 57/58, 461-470.

BERGHEM, L. E. R., \& PETTERSON, L. G. (1974): The mechanism of enzymatic cellulose degradation. Isolation and some properties of a $\beta$-glucosidase in T. viride. Eur. J. Biochem., 46, 295-305.

BULL, R. S. (1990): Advances in processes for fermentation ethanol. -in: KLASS, D. L. (Ed) Energy from biomass and wastes XIII. Institute of Gas Technology, Chicago, pp. 1263-1279.

CHAHAL, S. D. (1991): Bioconversion of hemicelluloses into useful products in an integrated process for food/feed and fuel (Ethanol) production from biomass. Biotechnol. Bioengng. Symp., 21, 425-433.

ChERNOGLAZOV, V. M., ERMALOVA, O. V. \& Klyosov, A. A. (1988): Adsorption of high-purity endo-1,4$\beta$-glucanases from Trichoderma reesei on components of lignocellulosic materials: cellulose, lignin and xylan. Enzyme microbial Technol., 10, 503-507.

CHRISTAKOPOUlOS, P., MAKRIS, J. B., \& KEKOS, D. (1990): On the mechanism of direct conversion of cellulose to ethanol by Fusarium oxysporum: effect of cellulose and $\beta$-glucosidase. Appl. Microbiol. Biotechnol., 33, 18-20.

COCHET, N. (1991): Cellulase of Trichoderma reesei: influence of culture conditions upon the enzymatic profile. Enzyme microbial Technol., 13, 104-109.

DuBois, M., GILLES, K. A., HAMILTON, J. K., REBERS, P. A. \& SMITH, F. (1956): Calorimetric determination of sugars and related substances. Anal. Chem., 28, 350-356.

EKLUND, R. (1994): Ethanol from wood: An experimental study of steam pretreatment, enzymatic hydrolysis and enzyme recovery. Doctoral thesis, Lund University, Lund, Sweden.

GAlBE, M., LARSSON, M., StENBERG, K., TengBorG, C. \& ZACCHI, G. (1997): Ethanol from wood: design and operation of a process development unit for technoeconomic process evaluation. -in: SAHA, B D. \& WOODWARD, J. (Eds) Fuels and chemicals from biomass. ACS Symp Ser 666, American Chemical Society, Washington, pp. 110-129.

GHOSH, P., PAMMENT, B. N. \& MARTIN B. R. W. (1982): Simultaneous saccharification and fermentation of cellulose: effect of $\beta$-D-glucosidase activity and ethanol inhibition of cellulases. Enzyme microbial Technol., 4, 425-430.

GROHMANN, K. (1993): Simultaneous saccharification and fermentation of cellulosic substrates to ethanol. Biotechnol. Agric. Ser., 9, 183-209.

HATZIS, C., RILEY, C. \& PHILIPPIDIS, P. G. (1996): Detailed material balance and ethanol yield calculations for the biomass-to-ethanol conversion process. Appl. Biochem. Biotechnol., 57/58, 443-586.

HÄGGLUND, E. (1951): Chemistry of wood. Academic Press, New York, pp. 324-332.

MANDELS, M., ANDREOTTI, R. \& ROCHE, C. (1976): Measurement of saccharifying cellulase. Biotechnol. Bioengng. Symp., 6, 21-33.

MILLER, G. (1959): Use of dinitrosalicylic acid reagent for determination of reducing sugar. Anal. Chem., 31, 426-428.

PHILIPPIDIS, P. G., \& SMITH, K. T. (1995): Limiting factors in the simultaneous saccharification and fermentation process for conversion of cellulosic biomass to fuel ethanol. Appl. Biochem. Biotechnol., 51/52, 117-123.

RÉCZEY, K., BRUMBAUER, A., BOLLÓK, M., SZENGYEL, ZS. \& ZACCHI, G. (1998): Use of hemicellulose hydrolysate for $\beta$-glucosidase fermentation. Appl. Biochem. Biotechnol., 70/72, 225-235.

SPINDLER, D. D., WyMANN, E. C., GROHMANN, K. \& PHILIPPIDIS, P. G. (1992): Evaluation of the cellobiosefermenting yeast Brettanomyces custersii in the simultaneous saccharification and fermentation of cellulose. Biotechnol. Lett., 14, 403-407.

SteNBERG, K., BOLlÓK, M., RÉCZEY, K., GALBE, M., \& ZACCHI, G. (2000): The effect of substrate and cellulase concentration in simultaneous saccharification and fermentation (SSF) of steam-pretreated softwood for ethanol production. Biotechnol. Bioengng. (in press). 